\title{
EUROPEAN SYMPOSIUM IN PRAGUE \\ Europe in transition -
the humanitarian perspective
}

The recent changes in Europe present new challenges for humanitarian organizations. How does the International Red Cross and Red Crescent Movement plan to meet them? What new possibilities do they provide for humanitarian endeavour? Such were the questions dealt with at a symposium held in Prague on 12 and 13 June 1990 and entitled "Europe in transition - the humanitarian perspective".

Some seventy representatives of 24 European National Societies, the League, the ICRC and the Henry Dunant Institute and eminent political, economic, social affairs and human rights experts took part in the symposium, which was organized by the League of Red Cross and Red Crescent Societies and the Czechoslovak Red Cross. Representatives of four National Societies from North and South America and from Asia also attended as observers.

Speaking at the opening ceremony, Mr. Vaclav Burian, President of the Czechoslovak Red Cross, said that the recent political, economic and social events in central and eastern Europe have opened the way to democracy, to political pluralism and a market economy; and they have created momentum which will help to safeguard human rights. The changes would have far-reaching consequences for the National Societies of Europe and should, he said, be viewed realistically. Human and financial resources should be mobilized to help rebuild the countries affected and to give new impetus to co-operation in Europe. Dr. Burian stressed the importance of the Red Cross and Red Crescent principles continuing to guide humanitarian endeavour, remarking that those principles were undeniably being instrumental in the resurgence of moral values.

Dr. Burian went on to describe the development of the Czechoslovak Red Cross and then advocated a number of reforms to make its work in behalf of the country's communities more effective and to win their support. In particular, the Society intends to make 
innovations in its medical and social welfare services, increase health education and its own role in improving the environment, promote first-aid training, disaster preparedness and youth programmes and knowledge of the Movement's principles and ideals.

Mr. Pär Stenbäck, League Secretary General, felt that the time had come to analyse the impact of the political, economic and military changes in Europe on humanitarian work. These changes, which were already affecting the countries of eastern, western and southern Europe engaged in a process of integration, would certainly make themselves felt throughout the continent. The new Europe which was emerging was already in a position to become a truly humanitarian continent.

Admittedly the opening of its borders, the so-called peace dividend, the rise in ethnic tensions and large-scale movements of people all represent an immense challenge for Europe. To meet this challenge, said Mr. Stenbäck, the National Societies would have to reorganize themselves and redefine their relationship with their respective governments. Assistance for European Societies must be based on careful analysis of all resources available and of the needs existing in the world, and must not neglect the most needy and vulnerable groups, notably those of the Third World.

Finally, Mr. Cornelio Sommaruga, President of the ICRC, said that the symposium provided the Red Cross and Red Crescent with an opportunity to look back at the past, reflect on the challenges of the present and decide for the future. He then submitted for consideration three words, three guidelines: honesty, trust and imagination.

First of all, he said, it must be acknowledged with honesty and humility that "history, external pressure and, on occasion, lack of boldness and compromise too readily accepted have cost the Red Cross some of its independence, neutrality and humanity". It was equally necessary to be honest in our perception of the major issues in the European countries - the influx of refugees, racism and discrimination, the inadequate protection of minority groups, the temptation to be selfish and narrow-minded, ecological dangers and unemployment.

Trust must be shown in tackling these problems, trust in the Movement's ideal which continues, despite the vicissitudes of history, to motivate humanitarian action and spur efforts to overcome indifference, selfishness, silent complicity and neglect.

But we must, he said, go further still and show imagination by constantly searching for ways of giving better help and being more active, more effective and more responsible while upholding the principles of independence, impartiality and universality. For the invincible nature of human dignity is at stake and must be defended despite 
injustice, violence or torture; international political life must be imbued with the values of solidarity and respect for the individual.

On the first day of the symposium, a number of experts gave lectures on political, social and economic changes in Europe. Adam Roberts, Professor of International Relations at Balliol College, Oxford, spoke on "Europe in transition from the historical perspective", whilst Jenoe Kovacs, member of the Hungarian Parliament's Commission for Human Rights, gave an analysis of "Europe in transition as seen by a politician". Alexander M. Vacic, Director of the Division for Economic Analysis and Projections of the UN Economic Commission for Europe, then lectured on "Europe's transitional economies - an economist's overview and forecast". Other lectures were given by Gervase Coles, Senior Legal Advisor to the UN High Commissioner for Refugees, who addressed the subject of "Uprooted people in a transitional Europe, as seen by an international civil servant", Vadim Zagladin, Advisor to the President of the USSR, who examined the origins of the transition process in Europe and new forms of co-operation between West and East, Rupert Neudeck, a journalist with the Frankfurter Rundschau who talked about the changes faced by the media, and Asbjørn Eide, Director of the Norwegian Human Rights Institute, who spoke on "Europe in transition - the humanitarian perspective".

All these speakers dealt with various aspects of the changes in Europe and stressed the interdependence of all the countries on the continent and the need to find joint solutions to problems such as mass migration, racism and environmental destruction. Recent political developments and the new importance attached to participation by the municipalities and non-governmental organizations open up new possibilities for the National Societies and the Movement, both in giving assistance to disadvantaged groups and in spreading knowledge of human rights and humanitarian law.

On the second day, the participants split up into four groups to discuss, respectively, migration and refugees; mobilizing resources; health and social welfare; and relations with other humanitarian organizations. 
As the purpose of this symposium was above all to assess the situation of the Red Cross in Europe and to examine the new possibilities opening up there for the National Societies in particular and the Movement in general, it reached no formal conclusions and adopted no resolutions.

The concerns of the participants were nevertheless made clear in the group discussions. Their suggestions may be summarized as follows:

\section{Migration/refugees}

- Launch public awareness campaigns to prevent hostility towards foreigners.

- Assist refugee integration in the host country.

- Facilitate voluntary repatriation by establishing ties with the country of origin.

\section{Mobilizing resources}

- Facilitate an exchange of information between European National Societies on legal restrictions on, and tax concessions to facilitate, fund-raising.

- Take part in a fund-raising seminar proposed by the Norwegian Red Cross for September/October 1991.

\section{Health and social welfare}

- Draw up a list of health and social welfare activities and select those which could be entrusted to properly trained volunteers.

- Involve young people more closely in decision-making.

- Plan the training of volunteers to meet needs related to new National Society activities.

- Encourage co-operation in the health and social welfare spheres between the central committees of the European National Societies.

- Plan a meeting for the European National Societies' advisers in health and social welfare.

\section{Relations with other humanitarian organizations}

- Draft a resolution for the 1991 International Conference recommending that in as many countries as possible the National Society should be responsible for the co-ordination of international aid received at the time of a natural disaster. 
- Organize a European Red Cross symposium in 1991 with the theme "How to develop a modern and competitive Society".

When the group meetings ended, a message from Mr. Vaclav Havel, President of the Czech and Slovak Federal Republic, was delivered by Ms. Vera Caslauska, his adviser for humanitarian affairs. President Havel welcomed the changes in the Czechoslovak Red Cross, which was thus reinstating its noble ideals, and stressed his government's firm intention of supporting the National Society's work.

Finally, the Netherlands Red Cross offered to host a European Regional Red Cross and Red Crescent Conference in 1992. 